\title{
Reel help for real life: Film therapy and beyond
}

\begin{tabular}{|c|}
\hline $\begin{array}{l}\text { Authors: } \\
\text { Philippa Strong }{ }^{1} \\
\text { George Lotter }^{1}\end{array}$ \\
\hline $\begin{array}{l}\text { Affiliations: } \\
{ }^{1} \text { Faculty of Theology, } \\
\text { North-West University, } \\
\text { Potchefstroom Campus, } \\
\text { South Africa }\end{array}$ \\
\hline $\begin{array}{l}\text { Correspondence to: } \\
\text { Philippa Strong \& George } \\
\text { Lotter }\end{array}$ \\
\hline $\begin{array}{l}\text { Email: } \\
\text { philippa.strong@nwu.ac.za; } \\
\text { george.lotter@nwu.ac.za }\end{array}$ \\
\hline $\begin{array}{l}\text { Postal address: } \\
\text { PO Box 20777, Noordbrug } \\
\text { 2522, South Africa }\end{array}$ \\
\hline $\begin{array}{l}\text { Dates: } \\
\text { Received: } 12 \text { Dec. } 2014 \\
\text { Accepted: } 14 \text { Feb. } 2015 \\
\text { Published: 08 May } 2015\end{array}$ \\
\hline $\begin{array}{l}\text { How to cite this article: } \\
\text { Lotter, G.A., Strong, P., } \\
\text { 2015, 'Reel help for real life } \\
\text { Film therapy and beyond', } \\
\text { HTS Teologiese Studies/ } \\
\text { Theological Studies 71(3), } \\
\text { Art. \#2878, } 8 \text { pages. http:// } \\
\text { dx.doi.org/10.4102/hts. } \\
\text { v71i3.2878 }\end{array}$ \\
\hline $\begin{array}{l}\text { Copyright: } \\
\text { (C) 2015. The Authors. } \\
\text { Licensee: AOSIS } \\
\text { OpenJournals. This work is } \\
\text { licensed under the Creative } \\
\text { Commons Attribution } \\
\text { License. }\end{array}$ \\
\hline
\end{tabular}

Read online:
In this article the background, development, therapeutical value and praxis of film therapy in Christian counselling will be addressed. The second part of the article shows what the scenery beyond film therapy may look like and how this form of therapy may extend to other areas of digital and electronic media in the current counselling and pastoral care praxis. Postmodernity, as the context within which the society finds itself, is discussed, as well as the place of films in postmodernity. The important use and application of narratives in the postmodern era is discussed. Film therapy's development as an outgrowth of bibliotherapy is explained. It is further shown how film therapy as a tool in the praxis of therapy may provide the ideal atmosphere for learning, enjoyment and edification. The scope of the article also reaches beyond the current use of film therapy by suggesting the use of other social and electronic media in a therapeutical way as an ever-increasing possibility. The article ends with some pointers in the use of film therapy.

\section{Introduction}

In the 70 years of its existence, HTS Teologiese Studies (HTS) has addressed many facets of theology and related disciplines and the journal and all the contributors throughout these years should be remembered and commended for the major contribution to academic research. A new phase was inaugurated when the Journal of Practical Theology in South Africa was moved under the wings of HTS and it broadened the scope of HTS with regard to practical theology. Also for this bold move HTS should be congratulated. This article falls within this new horizon which was created by HTS to publish online and the authors are grateful for it and congratulate HTS for this landmark.

The focus of the article is the Christian therapeutical value of film therapy - the process of using movies made for the big screen or television for therapeutic purposes - and how it can be enhanced and extended by related digital media within the context of postmodernity.

By using film therapy as a tool in therapy the ideal atmosphere for learning is created where enjoyment and edification are combined. As Albert Einstein advised in 1915 in a letter to his 11 year old son, Hans Albert: 'That is the way to learn the most, that when you are doing something with such enjoyment that you don't notice that the time passes' (Popova 2014).

Movies transcend all barriers and differences, whether these barriers are culture, language, religion, geographic borders, or belief systems (Niemiec \& Wedding 2014:3). Semiotics is described by Tomaselli and McLennan-Dodd (2005:224) as the examination of how signs, including words, pictures, gestures, sounds, shapes, colours, things, artefacts, smells, performance and so on, come to have meaning. One could say that semiotics is the international language of movies.

\section{Postmodernity}

The 21st century is characterised as the postmodern era (Anon 2013; Olthuis 1999:141; Olthuis 2012:3). According to Johnston (2004:33), 'What has popularly been labelled the move from late modernity to postmodernity in Western culture has brought with it fundamental changes in how we view reality'. In postmodernity the observer's experience (presuppositions which work unconsciously) is extremely important in the development of knowledge (Du Toit 2000:54; Olthuis 1999:144). People living in the modern age were focused on rules, facts and the grand narrative, whilst in Postmodernity the question is asked about significance (Freedman \& Combs 1996:22). According to Tak (2008:iii) postmodernism may be the phenomenon related to the spirit of the times, the mental structure, and the world view of the late 20th century, including the literature, art, and culture. Many believe postmodernism is the most profound societal change since the Enlightenment (Jones 2001:14) and undergirds all philosophical trends in the current era. The North American philosopher, James Olthuis (1999:140) states that the postmodern era not only 
open doors towards a post-secular discussion on faith, love and God, but it also encourages new and integrated forms of practical spirituality.

Regardless of believing that one is a postmodernist, one lives in the period of postmodernism and is affected by it on every level, whether one gives into its demands or not. Postmodernism is simply the water in which we swim now (Jones 2001:231). In order to communicate, live and breathe in this ongoing world, it's crucial to obtain a grip on postmodern cultural patterns and thought processes (Jones 2001:26). As Romanowski (2007:15) strongly argues, 'The realm of popular culture can be seen as an arena for argument or debate in which different ideas and perspectives find voice in stories, videos, songs, and pictures'. Furthermore, contemporary technology is in itself value-laden (PainterMorland \& Pistorius 2007:136).

\section{Place of films in postmodernity}

Christians have lately become more intentional about their engagement with popular culture (Dyrness 2001:13). In modernity the focus was very much on the cognitive, where rational thinking and logic had precedence, whereas in postmodernity, creativity and imagination are preferred. Narrative and the use of metaphors became dominant (Brunsdon 2010:2). Dyrness (2001:129) writes that the triumph of visual art is now widely recognised and that postmodern art represents almost in every respect the visual component and especially moving images. It is therefore clear that in the contemporary social, political, intellectual, emotional and spiritual spheres, growing practices and development are needed to adjust to the ever-changing milieu (cf. Olthuis 1999:140).

The narrative approach and story-telling became prominent themes in most of postmodernity's activities and metaphors for personal identity, relationships, and the process of healing in therapy (Brunsdon 2010:5; Olthuis 1999:144). Except for the different metaphors within postmodernity, there is also, '...the context of the Christian story and the Christian community' (Carter 2006:60). The use of inter alia film therapy in counselling and other therapeutical activities, fits neatly within postmodernity where a movie or a film is also a story or a narrative which can be used in therapy (Johnston 2006:95). Pecca (2011) also links film therapy with the ancient art of using stories as a teaching tool and indicates that stories were used to teach and inspire since the dawn of humankind and cave paintings.

Morbey (1995:66) takes this position even further by adding, 'Both photography and electronically-based imagery, little considered in the deliberations of Modern Art, have taken a central position in contemporary Western culture, a culture often categorised as postmodern'. In the same vein Johnston (2006:90) states '...movie going and the subsequent conversation it engenders - one of our common practises of everyday life - has become an important alternate source for spiritual (italics by authors) exploration'. Romanowski
(2007:17) remarks that, although movies can be fun, delightful, and entertaining, they can also communicate perspectives that deserve our careful consideration. A fascinating feature of film therapy is that it stimulates both sides of the brain (Joseph 1992:45, 61-63, 116; Strong 2001:35).

It has already been indicated back in 2001 by Strong (2001:104) that films can be used effectively in Christian counselling. This article provides a fresh take on the use of film therapy as a tool in therapy within a Christian context. It also explores the possibilities beyond film therapy - which involves the use of films in other forms of electronic social media. Film therapy serves in an excellent way the postmodern era we find ourselves in. As it includes both sensorical pleasure and spiritual healing and transformation, it embraces the principle, expressed by the Latin phrase utile dulci (the enjoyable is combined with the edifying). Olthuis (2012) aptly describes postmodernism and this is why the authors mean it provides a good space for film therapy:

Postmodernism attends to and makes room for the invisible, the unconscious, the emotional, all the non-rational ways of knowing; not as second-rate, subservient, irrational forces to be repressed, feared or discounted, but as necessary, indispensable co-contributors in the multidimensional process of human development. (p. 7)

In this respect it 'fulfils' the need mentioned by Olthuis (1999:140) earlier for a fresh approach in spiritual practices which can be helpful for Christian counselling.

\section{Film therapy}

Since the focus of this article is on film therapy, the following quote from Romanowski (2007) captures the essence of what this kind of therapy is about:

Movies, television, music, and videos provide a common experience for many people by addressing widespread concerns, fears, and prejudices and nurturing aspirations. ... and get us to look at things in new and different ways. They might explore challenging political, moral, economic, or religious issues by questioning gender relations or pointing a finger at sexism, racism, elitism, homophobia, and social or economic injustices. (p. 15; cf. also Johnston 2006:90)

In short Zhe $\mathrm{Wu}(2008: 6)$ describes cinema therapy as a creative, therapeutic intervention in which a therapist uses a film as a metaphorical tool to promote self-exploration, personal healing and transformation (cf. also Pecca 2011).

Perhaps in the remark by Niemiec and Wedding (2014:3) that movies are more than a commentary on society, and that they actually inform us of the human condition, lies the truth of the immense value the use of films in therapy can have.

Peter Weir calls himself first of all a storyteller, not a moviemaker. He believes that fiction, 'can give you a truth within its own set of lies' (cf. Johnston 2006:182) with which the authors agree wholeheartedly. Gary Solomon, author of The motion picture prescription and Reel therapy, often uses lectures at prisons to help inmates learn to use movies as 
therapy to see what they have done to land them into their current predicament and to learn from it (Mann 2007).

Strong (2001:86-88) gives examples of specific movies and how they may be used in certain circumstances to encourage the pastoral counselling process.

A good example of the impact of watching a movie clip and the effect it can have on a viewer has been illustrated by Beattie, Sale and McGuire (2011:121-124) where selected extracts from the film An inconvenient truth have been shown. A significant effect on the mood state as well as on the explicit social attitudes and cognitions of the people who watched these clips, was reported.

\section{How all arts are constituted, including film}

Art does not reproduce the visible; rather it makes visible. (Paul Klee [1879-1940], world renowned modern art painter)

The understanding of how all forms of art are constituted, and, in this case, how films relate to other arts, is important.

Begbie (2006:15-16) describes the three terms which constitute art, namely, Form, Inhalt and Gehalt as described by German-American theologian and philosopher, Paul Tillich (1886-1965) in his important work on the philosophy of art. Form has been described as the result of the artist's skill in mastering a particular artistic medium into a work of art. When one refers to a piece of art as a painting, one is referring to the form of the artwork. Inhalt denotes the subject-matter of the art work. Gehalt entails the unconditioned meaning presupposed - even if not intentionally - in the work of art, giving the art work its ultimate meaning or significance. Gehalt refers to the 'religious' element in art. Furthermore it is important to note that Form, Inhalt and Gehalt which constitute an artwork, are not of equal importance, e.g. the Inhalt of an art work is irrelevant in determining the extent to which Gehalt is revealed. In Tillich's (1959:22) words, translated by John P. Clayton (1980:20), 'Inhalt is the contingent element, Gehalt the essential one and Form the mediating agent'. Regarding the Gehalt of an artwork it is of utmost importance to note that an art work can be 'religious' irrespective of its Inhalt. On the other hand specifically religious themes or motives (e.g. the cross, scenes of life of Jesus) do not guarantee the disclosure of the 'religious' element of art (Begbie 2006:16). Dyreness (2001:140) stresses the 'religious' element (Gehalt) of art when he says that when we trivialise art, we fail to appreciate the power that our exposure to art inevitably holds, resulting in the fact that we overlook a vital area of potential Christian growth and witness. Johnston (2006:91) agrees when he remarks that the focal point of art - being the journey of the discovery towards the meaning of life - remained the same throughout the ages. Begbie (2006) boldly states:

Art is truly religious not when it employs traditional religious subjects, still less when it seeks a photographic depiction of reality, but when it probes beneath the surface of the finite and brings to light the ultimate meaning which lies beyond and beneath all things. (p. 20)
Films, which is art in own right, often have a powerful Gehalt element which contributes to the understanding of the meaning of life from a religious perspective. Perhaps the anecdote of Peter Weir (moviemaker) rings true where he said:

I belong to that tradition of entertainer or storyteller. There's this cartoon up on my wall of an old lady at a ticket box window, 'I want my sense of wonder back.' I like that idea. It's a desire to feel the sense of not knowing, that sense of danger and potential interlocked. It's very difficult to achieve, but the screen is one of the few places where it is possible (emphasis by authors). (cf. Johnston 2006:182)

\section{Films as popular art}

Popular art can be described as any dance, literature, music, theatre or other art form intended to be received and appreciated by ordinary people in a literate, technologically advanced society dominated by urban culture (Dyrness 2014). It further states that motion pictures may be an important medium of popular art, but in contrast to television, it can more often attain the same enduring appeal and significance as artworks belonging to the fine arts category.

Already in 1916 the Italian, F.T. Marinetti, the founder of futurism, in his manifest on film, said:

A new art, much more agile and vast than any other, yet, except for certain films on travel, hunting, wars, film-makers have done no more than inflict on us the most backward-looking drama, great and small. The cinema is an autonomous art. The cinema must therefore never copy the stage (emphasis by authors). (cf. Parkinson 1995:51)

Even in the modern age motion pictures became influential and a relevant form of art, with a television set found in almost every house and almost everyone exposed to the medium of film (Oliver 1998:25; cf. Johnston 2006:90).

At the beginning of the 21st century the printed media developed towards the moving picture and we find ourselves in a society which is dominated by visual stimulation. 'Picture motion' (moving pictures) captivates more senses than only seeing and hearing (Johnston 2006:95). Studies have shown that learning may happen multi-sensory, in the sense that we rely heavily on our senses in processing information when we are learning. Thus, the more senses are engaged in a teaching situation, the easier it is to process information, and the more is learned (Pitts 2012). Watching a movie is a multi-story experience, making film therapy an ideal tool not only in being more effective in teaching people new skills and concepts, but also in using it as catalyser in leading these people into catharsis. Detenber, Simons and Bennett (Jr) (1998:124) correctly observe that generally films enlarge the 'arousal level', the emotional experience, both on psychological- and subjective levels, and enhance the attention span of the audience.

Film as a visual form of art has the ability to entertain, becoming one of the main sources of entertainment during 
the twentieth century (Dockney \& Tomaselli 2012:103-104). As a form of art, film has more to offer than only entertainment; for instance an aesthetic experience which, in relation to other arts, is accessible and at the same time extremely relevant. According to Botha (1994:193) the re-evaluating of this form of art may also be more representative and currently applicable (cf. also Radall 2001:130). Film often impacts on the viewer because of the human factor which is a central characteristic of this form of art (Botha 1994:167; cf. Schultze et al. 1991:292).

Film usually evokes emotional, rather than intellectual responses from the viewer, and can lead to a catharsis where the viewer allows his or her emotions and internal conflicts to surface to the conscious mind (Randall 2001:131; cf. Louw 1997:314). Ironically people often watch movies in order to escape from the ordinary reality of life, resulting in finding themselves in the movies as 'an illusion of reality' (Strong 2001:86). The widespread accessibility of the content of movies and the intensity of experiences of movie-goers lead to the fact that movies are experienced as 'illusions of reality' (Noel \& Seeley 2013:53). Moreover, it is said that the moviegoing experience often departs from the ordinary experience, which enables movies to be a convincing power (Noel \& Seeley 2013:53; cf. Niemiec \& Wedding 2014:3).

As Johnston (2006:93) aptly remarks, 'Movies might not portray reality in a superficial sense, but they have the capacity to reveal life at a more central region - to show us our deepest selves' (emphasis by authors) (cf. also Gire 2000:44; Schultze et al. 1991:292) A variety of artistic media like music, words, dance, drama, pictures, architecture, and more, is used to communicate with the viewer (Johnston 2006:95). Film is a complex form of art which has the ability to create or recreate an all-encompassing environment, whilst it has the unique capability to interpret the full experience, as it has the ability to express a wide variety of artistic nuances by internalising sounds, forms, images and words (Johnston 2006:96). Recently movie theatres have added 4D cinema to their experience list. This $4 \mathrm{D}$ cinema format allows cinema viewers to experience moving seats, strobe lighting, bubbles floating from the ceiling and 1000 different scents (Widdall 2013). Starting with Iron Man 3, the first 4 D cinema in Japan, located in Nagoya, started screening 12 movies a year in $4 \mathrm{D}$ on 12 April 2013.

People generally absorb images, lyrics, music, rhythm, stories and other sensorical information and weave this data into their own dreams and relationships and thereby connect socially. Facebook, Twitter and other electronic media (as will be indicated later in the article) are increasingly popular for connecting.

Films and the above mentioned electronic media can help people to develop their own identity, friendships and to better comprehend the significance of life. Already in 1991 Schultze et al. (pp. 292-293) claimed that popular art has an advantage over the usual institutions of education, and also a bigger and more effective way of influence on the youth than parents and teachers. Although the authors agree with them on the big influence that popular art has on youth, they disagree that it is more powerful that the influence that parents have on their youth. Films - as popular art - can be used effectively by parents to impart certain values to their children, or, on the other hand, used as tool to caution their children against certain influences. As Mitchell Stevens (1998) aptly remarks about the power of film:

Moving images can cut in, cut away, dance around, superimpose, switch tone or otherwise change perspective, without losing their audience's attention; they can encompass computerized graphics, even words. Seeing, consequently, can become a more complex activity; we might see from more perspectives. For when video is cut fast, it allows the interchanging and juxtaposition not just of actions within a scene, not just of angels upon a scene, but of entire scenes themselves - dozens of them. Printed words risk their believability and entertainment value when they attempt such maneuvers. (p. xi)

\section{Film therapy as an outgrowth of bibliotherapy}

Cinema therapy has emerged as an outgrowth of bibliotherapy using films or movies as metaphor to create indirect but powerful therapeutic interventions in marriage and family counselling (Zhe Wu 2008:2; cf. also Pecca 2011). Bibliotherapy on its own merits can be defined as the use of reading materials for promotion of mental health, help in solving personal problems or for psychiatric therapy (cf. Jeon 1992:16; Hesley 2000:55; Merriam-Webster Online Dictionary 2014).

Apparently Sir Walter Galt already catalogued fiction in 1840, as well as non-fiction literature, as advised by psychiatrists to use as a tool to help in religious as well as moral support and education of hospitalised psychiatric patients (Hesley \& Hesley 1998:5). This initial endeavour developed into bibliotherapy as it is now known (Hesley \& Hesley 1998:5-6; cf. Pecca 2011). In 1981 Halsted identified four stages in bibliotherapy, namely, identification, catharsis, insight and universalisation (see Halsted 2009: 111-112; cf. Jeon 1992:16). Identification is where the viewers see similarities between themselves and the characters in the story. Catharsis is the point where the client allows his emotions and internal conflicts to surface to the conscious mind. Insight is when the client makes a connection between him or herself and the character. Lastly, universalisation, where clients understand that their problems are not unique and that they are capable to search for different and effective methods to deal with their problems. Universalisation also has the positive result that clients now feel able to handle their problems, whereas in the past it could have had powerlessness as a consequence. Newton names these four stages as the common grounds between bibliotherapy and film therapy (cf. Newton 1995:15). In a certain sense film therapy and bibliotherapy share the same advantages, limitations and objectives (cf. Hesley \& Hesley 1998:7).

The most prominent difference between film therapy and biblioterapy is that the former uses fiction whilst the 
latter today uses non-fiction more dominantly (Hesley \& Hesley 1998:6-7). Nowadays fictional books are used in bibliotherapy especially to help children overcome emotional problems (Anon 2013; Barancik 2014). It is necessary to mention that inspirational DVDs can be used in film therapy to teach a client certain life skills. However, in biblioterapy non-fictional self-help resources are mostly used to provide guidelines for correct behaviour through providing scenarios taken from real life situations. In contrast with this, in film therapy films portray everyday life and may lead clients in their specific situations to serve as catalyser (used as a tool to initiate the counselling procedure) in the process of catharsis (a Greek term, where the viewers allow their emotions and internal conflicts to surface to the conscious mind) (Eldridge 2006:42; Louw 1997:314; Randall 2001:131). According to Eldridge (2006:42), 'Aristotle goes on to make it clear that in the case of tragic drama, in particular the point of artistic representation - is the catharsis of emotions' (emphasis by authors). Films provide a wide series of events which can be easily connected to the specific context of the client, whereby the therapist helps the client to connect his or her own life with the story of the film.

In terms of strategy, film therapy also differs from bibliotherapy (Hesley \& Hesley 1998:7). In bibliotherapy the client discovers his own application by reading mainly nonfiction self-help literature, whereas in film therapy, film can be used to practically confirm that which had been discussed earlier in therapy (cf. Hesley \& Hesley 1998:7). More recently, Mann (2007), in discussing 'evocative cinema therapy' suggested one should ask whether there were any characters in the movie who modelled behaviour that you would like to emulate and in which way one could imitate 'reel' in real life. In film therapy film is mainly used as a tool to uncover the issue, leading the client to catharsis, describing and understanding the problem: it does not in most circumstances provide the application but rather uncover and describe the problem.

A good application can be when someone watches a movie alone (or with someone else), and then identify his or her frame of reference which had not been recognised before, or a wound that has long been covered and had not been dealt with in therapeutic context.

From another point of view, Heidegger's observation of human capacity for resolution (Entschlossenheit) and releasement (Gelassenheit) can be understood in the method of film therapy. Resolution can be described as when one bravely faces up to the limits of existence, recollecting the past and anticipating the future, whereby, in releasement one reaches out and expand to what is beyond and rely on it to be safe enough to surrender oneself to it (cf. Van Deurzen 2012).

Some of the advantages of movies are that it is fun to watch movies (and other media on any screen) and takes little time, while most people are involved in these activities as part of their daily routine. In following Stuart Fischoff, already in 2001, Randal (2001:130) suggested that films replaced books and reading as the lingua franca of contemporary society. People are, therefore, keener to watch movies (in any form) which will address their problems than for instance reading a book (cf. Hesley \& Hesley 1998:9). Logically, therefore, 'homework' that is given in film therapy by the counsellor to the counselee is carried out more regularly and enthusiastically than 'homework' that is given in a bibliotherapy setting. This is as a result of humans' inherent laziness and also people's addiction to the media in any form, which is in its extreme form described by Lotter (2006:2) as cyberaddiction. However film therapy uses the love of movies as an advantage for therapeutic purposes and does not in any way encourage cyberaddiction.

Bearing these factors in mind, combined with the entertaining value and attractiveness of media of any kind, makes film therapy, and other related media, in service of caring for people in a more structured way, excellent tools. Strong had already indicated 13 years ago that film therapy may be used successfully as a therapeutic tool in a counselling context (Strong 2001:19-20). In research on the use of movies in therapy, Mann (2007) states the following:

An increasing number of therapists prescribe movies to help their patients explore their psyches. And while few therapists have actually gone so far as to package their practices around cinema therapy, movies - like art, books, and music - are becoming one more tool to help those in therapy achieve their goals and overcome their hurdles. (n.p.)

\section{Beyond film therapy}

With the growth of the internet and the increasing development of all kinds of media available on different devices, the possibility of using the social and electronic media in a variety of ways for therapeutic purposes, is ever expanding.

Some of these are Twitter, YouTube, LinkedIn, Tumblr, Reddit, and Vine. Pinterest, Instagram and Facebook remain the dominant social networking platforms (Duggan \& Smith 2013).

As was indicated above, other forms of media may also be used for therapeutical purposes; however caution should be taken in selecting the specific method to be used. The reasons for taking proper measures are:

- The possibility of Internet addiction, which is the term used to describe excessive and problematic use of the Internet. It can also be defined as an uncontrollable and damaging use of the Internet which is recognised as a compulsive-impulsive disorder (cf. Grohol 2013). The possibility of cyberaddiction also exists as described by Lotter (2006:2), which may include addiction to any kind of media.

- Often these kinds of social media cannot be controlled in a context of therapy.

- Poor people skills could be the reason why people are addicted to the Internet. Parental Alienation Disorder, 
concerning which the authors agree wholeheartedly with Grohol (2013) who regards it as not being a disorder but a relationship problem - but which exists because of poor parent-child relationships. Many times these young people hide behind the Internet or other social media instead of facing their relationship with their parents.

- Dangers of using inter alia chatrooms - which can lead to enlargement of current problems or expose the person to more unhealthy features.

Social media can also be incorporated in a positive way in therapy. Pinterest (named earlier as one of the most dominant social networking platforms) has a pin board called 'School Counselling Videos' which also includes YouTube videos which can be used in therapy (Savvy School Counselor Vanessa 2014). This is a highly demonstrative way of how film therapy can be used effectively in combination with the social media which are used intertwined, in this case Pinterest and YouTube.

Other examples of the possibilities in using the vast electronic media, are e-mentoring (Lotter 2010:4), e-coaching and e-counselling, which per se have its own advantages and disadvantages. In the same vein Fourie (2005:141) shows the ability of television and the internet as dominant forms of mass communication media of our times.

Although film therapy in some ways developed out of bibliotherapy, it is a unique practice and has, for most people, many more exciting characteristics, and provides new possibilities, mainly because it stimulates more senses.

\section{Praxis of film therapy}

Film therapy can easily be used as a tool in connection with other therapies, in the same way as art therapy is used as a tool. Niemiec and Wedding (2014:3) directly connect positive psychology and the use of films with each other, whilst already in 2001 Strong proposed film therapy from a theological perspective, indicating the positive characteristics of film being used as tool in pastoral counselling (Strong 2001:114).

Gary Oliver (1998) confirmed the value of films being used as tool in counselling, when he says:

A well-chosen video can help our clients learn 'reel' life lessons from their world. They can watch the characters develop, destroy, and rebuild relationships; exercise problem solving (and in some cases problem causing) skills; pursue different solutions based on a variety of values; and experience the shortterm and long-term consequences of their choices (p. 25; cf. also Heston \& Kottman 1997:92; Mann 2007; Pecca 2011)

\section{Pointers for the use of film therapy}

As was indicated earlier in this article, film therapy is proposed as a tool in the therapeutical process by the counsellor in the counselling of someone. The following pointers of how to incorporate films or film snippets effectively in counselling are suggested.

Movies do not replace the guidance of the counsellor: It is important to note that film therapy in no way implies that the therapeutic process - where a counsellor guides a counsellee - is replaced by the watching of a prescribed movie. One allows the movie, which works as a tool in relating to the problem which is directly applicable to the life of the counsellee. It could lead the counsellee into a position of catharsis, proceeding into possible understanding, even a solution to the problem of bad communication in, for instance, a father-daughter relationship.

Movies should be used as tools in therapy: Movies or certain themes in a movie can serve as a metaphor, enabling the client to understand his or her life better from an 'observing' perspective.

Collect a variety of well-selected movies or snippets of movies, which cover different themes: An inspirational movie rated for all ages would be ideal; however, if the counsellor wishes to use an age restricted movie which includes sex, violence or bad language, it may do so. In such a case, it is important to discuss these aspects with the counsellee, making your stance as counsellor clear pertaining to bad language, etc., in movies and also sketching the guidelines of the Bible towards these aspects. The counsellee should never gain the idea that the counsellor supports bad language, nudity, and so forth, or in some way agrees with the negative use of it in movies. Sometimes these aspects in a movie may bring to the surface the relevant issues to deal with in the life of the counsellee. Many times movies include a variety of themes and sub-themes, as well as positive and negative depictions of the same theme (Strong 2001:101). The father-daughter relationship in the movie, The big wedding (2013), portrays an excellent example of a father-daughter relationship that turned sour and was eventually restored. This movie also contains other themes which can be used in different counselling situations.

Allow the client to watch the movie or clip unrestricted: The authors disagree with Niemic and Wedding (2014:4) when they say that they believe that in all cases reading and learning about a movie before seeing it, enriches the cinematic experience. The authors' point of view is that the most effective way for a person to understand the Aha Erlebnis is to watch the movie or clip unrestricted, without any prescribed precautions and prescriptions. Allowing the client to watch the movie for pure enjoyment, have the result of the movie staying in the entertainment category and the art to play its 'magic' on the counsellee. Movies are a popular art and should be allowed, like any other art, to be interpreted freely and without any prescription to the viewer, since it is a privilege of art to 'speak' to every viewer in its own unique way. Sometimes people need to loose themselves in order to find themselves, and movies allow one to do just that (Noel \& Seeley 2013:53). 
Movies can help the counsellor to obtain the picture from the client's perspective: Movies can also be very helpful in assisting a counsellee to describe to a counsellor the position, dilemma or frame of mind in which he or she finds herself. The animation movie, Justin and the Knights of Valour (2013), provides such an example, where Justin in a state of frustration describes to his grandmother that his father wants him to go to law school, but he desires to be a knight.

Fictional, inspirational, animation films and motivational DVDs may be prescribed as homework in therapy: The use of motivational DVDs can specifically be used effectively in the learning of new skills and lifestyle development; the DVDs of Dr Wayne W. Dyer are an excellent example. Using movies in this way in therapy is identically to the developmental stage of bibliotherapy (identified by Halsted in 1981 [see Halsted 2009]), where books are prescribed especially to kids to facilitate their normal personal development and selfactualisation (cf. also Jeon 1992).

Old and new movies can be used in film therapy: As movies are a form of art, their power will stay the same, whether it is 2 months or 20 years old. Although the movie Life is beautiful was released in 1997, it is a classic example of the timeless application of movies. Every time this movie is watched, it enthrals audiences with an appreciation of life. The recent movie, Noah (2014), although controversial, for instance caused people to go back to reading the original biblical narrative.

These pointers are not complete, but they aim to give a broad guideline of how film therapy can be practically implemented in a therapeutical situation.

\section{Conclusion}

In the article it has been indicated that the postmodern era creates the possibility and space for film therapy. According to the literature, film therapy may be used in all kinds of therapy. This is because of the characteristics of this kind of media, using a variety of arts to communicate and therefore being ideal for 'real help' and supporting people in using films and other media to reach a catharsis and identifying themselves with what they see and experience. The expansion of the digital media broadening the already available possibilities of film therapy opened even larger horizons in the therapeutic use and help of people. Developments in social media not only enlarged the exposure to narrative ways of helping people who need counselling, but are also easily available for anyone in an entertaining way. The dangers of social media are briefly discussed and positive ways of incorporating social media together with film therapy are provided, whilst, finally, pointers are given how film therapy may be used.

It is clearly evident that film therapy - which nowadays may also be used intertwined with other electronic social media - has developed into an independent therapy which can be used successfully as an exciting and effective tool for a variety of therapeutic and learning outcomes. Film therapy is a cutting edge tool in this regard. It fits neatly into the cultural context of a story hungry society, providing both the therapist and the client or learner with pure enjoyment.

\section{Acknowledgements Competing interests}

The authors declares that they have no financial or personal relationships which may have inappropriately influenced them in writing this article.

\section{Authors' contributions}

Although the article is taken mainly from the master's thesis of P.S. (North-West University) with G.L. (North-West University) as her supervisor at the time, it is now reworked and expanded by both authors, now colleagues at NorthWest University.

\section{References}

Anon, 2013, Bibliotherapy booklists: Helping young children cope in today's world viewed 31 March 2014, from http://www.carnegielibrary.org/research/ parentseducators/parents/bibliotherap/

Barancik, S., 2014, Bibliotherapy: Good book ==> happier kid?, viewed 31 March 2914 from http://www.best-childrens-books.com/bibliotherapy.html

Beattie, G., Sale, L. \& McGuire, L., 2011, 'An inconvenient truth? Can a film really affect psychological mood and our explicit attitudes towards climate change?', Semiotica 187(1/4), pp. 105-125. http://dx.doi.org/10.1515/semi.2011.066

Begbie, J.S., 2006, Voicing creation's praise: Towards a theology of the arts, T \& T Clark, New York.

Botha, J.R., 1994, 'Die rolprent as dié kunsvorm van die twintigste eeu', reeks J, nr. 45, Instituut vir Reformatoriese Studie, Potchefstroom.

Brunsdon, A.R., 2010, 'n Narratiewe benadering tot die pastoraat: Kritiese opmerkings na aanleiding van die huidige teologiese debat', Acta Theologica 30(2), 1-20.

Carter, C.A., 2006, Rethinking Christ and culture: A post-Christendom perspective, Brazos, Grand Rapids.

Detenber, B.H., Simons, R.F. \& Bennett (Jr), G.G. 1998, 'Roll'em!: The effects of picture motion on emotional responses', Journal of Broadcasting \& Electronic Media 42(1), 113-127. http://dx.doi.org/10.1080/08838159809364437

Dockney, J. \& Tomaselli, R., 2012, 'Fit for the small(er) screen: Film, mobile TV and the new individual television experience', in Z. Lesame, B. Mbatha \& $S$. Sindane (eds.), New media in the information society, pp. 103-112, Van Schaik, Pretoria.

Duggan, M. \& Smith, A., 2013, Social media update 2013, viewed 14 March 2014, from http://www.pewinternet.org/2013/12/30/social-media-update-2013/

Du Toit, B., 2000, God? Geloof in ' $n$ postmoderne tyd, CLF-Uitgewers. Bloemfontein.

Dyrness, W.A., 2001, 'Visual faith: Art, theology, and worship in dialogue', viewed 28 March 2014, http://global.britannica.com/EBchecked/topic/470196/popular-art

Eldridge, R., 2006, An introduction to the philosophy of art, Cambridge University Press, Cambridge.

Freedman, J. \& Combs, G., 1996, Narrative therapy: The social construction or preferred realities, W.W. Norton \& Company, New York.

Fourie, P.J., 2005, 'Differences and similarities between the telespace and the cyberspace: the metamorphosis of a medium', Tydskrif vir Geesteswetenskappe $45,141$.

Gire, K., 2000, Reflections on the movies: Hearing God in the unlikeliest of places, Victor Cook Communications, Jersey City.

Grohol, J.M., 2013, Not in the DSM-5: Internet addiction \& parental alienation disorder viewed 31 March 2014, from http://psychcentral.com/blog/archives/2013/05/29/ not-in-the-dsm-5-internet-addiction-parental-alienation-disorder/

Halsted, J.W., 2009, Some of my best friends are books: Guiding gifted readers, Great Potential Press, Scottsdale.

Hesley, J.W. \& Hesley, J.G., 1998, Rent two films and let's talk in the morning: Using popular movies in psychotherapy, John Wiley \& Sons, New York.

Hesley, J.W., 2000, 'Reel therapy', Psychology Today 33(1), 54-57.

Heston, M.L. \& Kottman, T., 1997, Movies as metaphors: A counseling intervention, viewed 21 July 2000, from http://www-sa.ebsco.com

Jeon, K.W., 1992, 'Bibliotheraphy for gifted children', The Gifted Child Today 15, 16-19.

Johnston, R.K., 2004, Useless beauty: Ecclesiastes through the lens of contemporary film, Baker, Grand Rapids. 
Johnston, R.K., 2006, Reel spirituality: Theology and film in dialogue, Baker, Grand Rapids.

Jones, T., 2001, Postmodern youth ministry, Zondervan, Grand Rapids.

Joseph, R., 1992, The right brain and the unconscious: Discovering the stranger within, Plenum Press, London. http://dx.doi.org/10.1007/978-1-4899-5996-6

Klee, P., 1879-1940, viewed 20 March 2015, from www.quotes-famous-artists.org/ paul-klee-famous-quotes

Lotter, G.A., 2006, 'Dehumanization by cyberfication', paper presented at IPS| Conference, Marbella, 12-14 February.

Lotter, G.A., 2010, 'E-mentoring as effective tutoring tool in higher education', in A. Koch \& P. van Brakel (eds.), Proceeding of the 12th annual conference on world wide web applications, pp. 4-15, Durban, South Africa.

Louw, D.J., 1997, Pastoraat as vertolking en ontmoeting: Teologiese ontwerp vir ' $n$ basisteorie, antropologie, metode en terapie, Lux Verbi, Kaapstad.

Mann, D., 2007, 'Movie therapy: Using movies for mental health: Therapists recommend movies to help change the way we think and feel', viewed 12 February 2014, from http://www.webmd.com/mental-health/features/movietherapy-using-movies-for-mental-health

Merriam-Webster Online Dictionary, viewed 19 January 2014, from http://www merriam-webster.com

Morbey, M.L., 1995, 'Stories into cyberspace: Art and electronic technologies', in L. Zuidervaart \& H. Luttikhuizen (eds.), Pledges of jubilee: Essays on the arts and culture, in Honor of Calvin G. Seerveld, pp. 56-77, William B. Eerdmans Publishing Company, Grand Rapids.

Newton, A.K., 1995, 'Silver screens and silver linings: using theatre to explore feelings and issues', Gifted Child Today 18, 14-19, 43.

Niemiec, R.M. \& Wedding, D., 2014, Positive psychology at the movies: Using films to build character strengths and well-being, Hogrefe Publishing, Boston.

Noel, C. \& Seeley, W.P., 2013, 'Cognitivism, psychology, and neuroscience: Movies as attentional engines, in A.P. Shimamura (ed.), Psychocinematics: Exploring cognition at the movies, pp. 53-75, Oxford University press, New York.

Olthuis, J.H., 1999, 'Dancing together in the wild spaces of love: Postmodernism, psychotherapy and the spirit of God', Journal of Psychology and Christianity 18(2), 140-152.

Olthuis, J.H., 2012, 'A vision of and for love: Towards a Christian post-postmodern worldview', Koers - Bulletin for Christian Scholarship 77(1), Art. \#28.

Oliver, G.J., 1998, '“Reel” life lessons', Christian Counseling Today 6(4), 25.

Painter-Morland, M. \& Pistorius, C., 2007, 'Technology and moral regeneration', Journal of Humanities $47,2$.
Parkinson, D., 1995, History of film, Thames and Hudson, London.

Pecca, T., 2011, Art fixes life: Cinema therapy, viewed 28 March 2014, from http://www. health24.com/Mental-Health/Treatment/Art-fixes-life-cinema-therapy-20120721

Pitts, A., 2012, Learning is multi-sensory: How to engage all the senses so children really benefit, viewed 28 March 2014, from http://www.howtolearn.com/2012/12/ learning-is-multi-sensory-how-to-engage-all-the-senses-so-children-really-benefit/

Popova, M., 2014, The secret to learning anything: Albert Einstein's advice to his on viewed 28 March 2014, from http://www.brainpickings.org/index. php/2013/06/14/einstein-letter-to-son/

Randall, L., 2001, 'Popcorn therapy', Shape, pp. 130-131, March.

Romanowski, W.D., 2007, Eyes wide open: Looking for God in popular culture, Brazos Press, Grand Rapids.

Savvy School Counselor - Vanessa, 2014, School counseling videos, viewed 31 March 2014, from http://www.pinterest.com/vanvan2289/school-counseling-videos/

Schultze, Q.J., Anker, R.M., Bratt, D.J., Romanowski, W.D., Worst, J.W. \& Zuidervaart, L., 1991, Dancing in the dark: Youth popular culture and the electronic media, Eerdmans, Grand Rapids.

Stevens, M., 1998, The rise of the image, the fall of the word, Oxford, New York.

Strong, P., 2001, 'Die gebruik van filmterapie in pastorale berading, MA tesis, PU for $\mathrm{CHO}$, Potchefstroom

Tak, S.C., 2008, 'Communication through sermon for the Korean church in a postmodern period', MA thesis, RTS Jackson, Mississippi.

Tillich, P., 1959, 'Gesammelte Werke, IX, p.22', in J.P. Clayton (transl.), The concept of correlation: Paul Tillich and the possibility of a mediating theology 1980, 197.

Tomaselli, K.G. \& McLennan-Dodd, V., 2005, 'Cinema as visual culture: Making sense via semiotics', in J. van Eeden \& A. du Preez (eds.), South African visual culture, pp. 224-241, Van Schaik, Pretoria.

Van Deurzen, E., 2012, Existential counselling and psychotherapy in practice, SAGE Publications Ltd, Thousand Oaks.

Widdall, C., 2013, 'Japan's first 4D movie theatre to open with Iron Man 3', viewed 07 February 2014, from http://tokyodesu.com/2013/04/17/japans-first-4d-movietheatre-to-open-with-iron-man-3/

Zhe Wu, A., 2008, 'Applying cinema therapy with adolescents and a cinema therapy workshop', MSc thesis, partial fulfilment, California State University, East Bay. 